\title{
Изучение разнообразия водорослей в почвах под растительностью с Бамбучником на острове Итуруп с использованием молекулярно-генетического подхода
}

\author{
(С) А.Ю. Никулин ${ }^{1 *}$, В.Б. Багмет ${ }^{1}$, В.Ю. Никулин ${ }^{1}$, Ш.Р. Абдуллин ${ }^{1}$ \\ ${ }^{1}$ Федеральный научный центр биоразнообразия наземной биоты Восточной Азии \\ ДВО РАН
}

Россия, Приморский край, 690022, г. Владивосток, проспект 100-летия

Владивостока, 159.

\section{`Email: artyrozz@mail.ru}

Получены первые данные по биоразнообразию водорослей в почвах под растительностью с Бамбучником - Sasa kurilensis (Rupr.) Makino \& Shibata на о. Итуруп с применением классических альгологических и молекулярно-генетических методов. Обнаружено 13 видов водорослей, относящихся к 10 родам, 10 семействам, 7 порядкам, 4 классам и 3 отделам: Bacillariophyta - 3 вида, Ochrophyta - 3 вида, Chlorophyta - 7 видов. Аpeaлы выявленных видов зачастую очень обширны или еще не до конца установлены. Низкое видовое богатство изученных проб связано, по-видимому, с сильной затененностью местообитаний с Бамбучником.

Ключевые слова: биоразнообразие, почвенные водоросли, полифазный подход, Sasa kurilensis, остров Итуруп.

Природа Курильских островов представляет большой интерес для исследования биоразнообразия своей изолированностью от континента и влиянием умеренно холодного муссонного климата. На этих островах проводились исследования пресноводных водорослей $[1,2,3]$. При этом таксономическое разнообразие почвенных водорослей на острове Итуруп остается практически не изученным. Известна лишь работа К. В. Ильчибаевой с соавторами [4], посвященная предварительным сведениям о цианобактериях и водорослях вулканических почв Курильских островов. В 12 пробах было выявлено 23 вида цианобактерий и водорослей: Cyanobacteria - 5 видов, Bacillariophyta - 5 видов, Ochrophyta (Xanthophyceae - 1), Chlorophyta (Chlorophyceae - 11, Trebouxiophyaceae - 1). Бамбучник (Sasa kurilensis) произрастает на Сахалине и Курильских островах, часто образуя непроходимые заросли на склонах гор и опушках лесов. Почвы под исследуемыми сообществами - дерново-перегнойные охристые буроземы. Их отличительной чертой является высокая гумусированность. Это также характерно для почв фритоценозов под каменноберезовыми лесами с дубом курчавым и ольхой волосистой. Кроме того, в почвах под лесными экосистемами отмечены более низкие значения $\mathrm{pH}$ и валового содержания основных оксидов по сравнению с почвами луговых сообществ [5,6]. При этом вполне вероятно, что в почвах под Бамбучником могут образовываться уникальные ценозы микроорганизмов, включая и водоросли, которые ранее под растительными сообществами с S. kurilensis не исследовались. Поэтому цель нашей работы - анализ биоразнообразия водорослей почв острова Итуруп под растительными сообществами с Бамбучником.

С 27.07.2018 по 05.08.2018 в шести точках, расположенных в центральной части острова и включающими растительные сообщества с Sasa kurilensis были отобраны пробы почвы по общепринятой методике [7]. 
Клетки изучали с использованием светового микроскопа (Olympus BX 53 (Japan), оборудованного оптикой Nomarski DIC и цифровой камерой Olympus DP27), а также сканирующей электронной микроскопии (СЭМ; Merlin, Carl Zeiss, Germany). Для идентификации выделенных штаммов водорослей определялись последовательности внутреннего транскрибируемого спейсера ядерной рибосомной ДНК (ITS-региона ярДНК). Все вновь полученные последовательности были помещены в GenBank под регистрационными номерами MW013805-MW013816 и сравнивались с другими штаммами, доступными с помощью поиска BLAST (https://blast.ncbi.nlm.nih.gov/Blast.cgi [8]).

Всего выявлено 13 видов водорослей, относящихся к 10 родам, 10 семействам, 7 порядкам, 4 классам и 3 отделам: Bacillariophyta - 3 вида, Ochrophyta - 3 вида, Chlorophyta - 7 видов (табл.). Три вида удалось идентифицировать лишь до рода, для дальнейшего уточнения их таксономической принадлежности необходимы дополнительные исследования. Наиболее часто встречался вид Coelastrella aeroterrestrica Tschaikner, Gärtner \& Kofler ( $F=67 \%)$. Большинство видов отмечено лишь единично. Число видов в пробе было низким и варьировало от 2 до 5 (табл.).

В трех пробах почвы обнаружено три вида Bacillariophyta (табл.). В точках 3 и 5 отмечен Humidophila contenta (Grunow) Lowe, Kociolek, J.R. Johansen, Van de Vijver, LangeBertalot \& Kopalová - повсеместно встречающийся вид, обитающий в пресных водах, наземных местообитаниях и в привходовых частях пещер $[9,10]$. Данный таксон отмечен и в России, и на территории Российского Дальнего Востока (РДВ). На острове Итуруп ранее был выявлен в пресноводных местообитаниях [2]. Mayamaea arida (Bock) Lange-Bertalot - пресноводный вид, аэрофил, отмечен в бентосе биотопов с низкой $\mathrm{pH}$, развивается в сфагновых болотах и на мхах. Является новым видом для Российского Дальнего Востока (РДВ). Mayamaea fossalis (Krasske) Lange-Bertalot - аэрофил, предпочитает увлажненные местообитания, в частности, почвы, а также временные водоемы, распространен в Голарктике. На острове Итуруп ранее не отмечался.

Отдел Ochrophyta был представлен тремя видами (табл.), два из которых относятся к роду Vischeria: Vischeria magna (Petersen) Kryvenda, Rybalka, Wolf \& Friedl (рис. 2г; два генетически идентичных штамма: MW013812 и MW013815 из проб 4 и 5 соответственно и V. vischeri (Hibberd) Kryvenda, Rybalka, Wolf \& Friedl (проба 2; MW013808; табл.). Оба вида широко распространены в разнотипных почвах и аэрофитных местообитаниях, и для них отмечено большое число находок на территории бывшего СССР, включая Дальний Восток и Курильские острова [4, 11]. На острове Итуруп ранее виды не отмечались. Monodopsis subterranea (J.B. Petersen) D.J. Hibberd встречается в разных типах почв. Данный таксон выявлен в России, включая Приморский край, Дании, территории бывшей Чехословакии, Румынии, Антарктике. На острове Итуруп ранее не отмечался.

Из отдела Chlorophyta были выявлены семь видов (табл.). Chlamydomonas sp. - потенциально новый вид, характеризующийся низкой идентичностью ITS-региона ярДНК по результатам BLAST (89\%). По морфологическим данным вид также однозначно принадлежит Chlamydomonas. Требуется дальнейшее изучение жизненного цикла штамма, получение дополнительных фрагментов ярДНК для описания нового таксона. 
Таблица. Таксономический состав водорослей из проб почв под сообществами с Бамбучником (остров Итуруп, Сахалинская область)

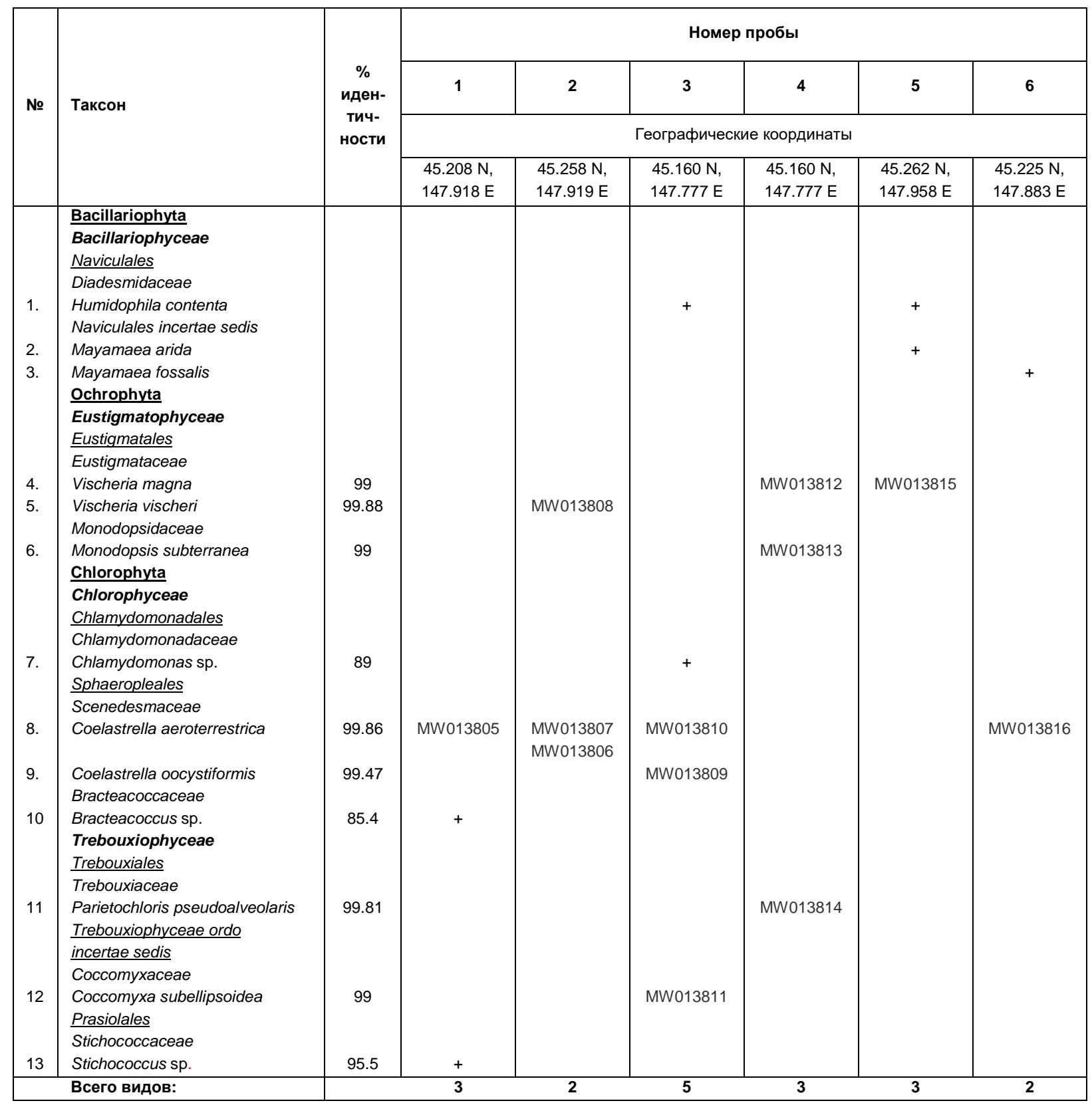

Coelastrella aeroterrestrica - всего выделено 5 штаммов из 4 проб (MW013805MW013807, MW013810, MW013816; табл.). Три штамма (MW013805, MW013810, MW013816; точки 1, 3, 6 соответственно) оказались идентичны друг другу (табл., рис. 1). Еще два штамма генетически незначительно отличаются от вышеуказанных MW013806 (1 замена) и MW013807 (3 замены, одна делеция) и между собой (2 замены, одна делеция), причем оба они были из одной пробы, отобранной в точке 2 (табл). Отмечена высокая встречаемость данного вида в пробах (треть от всех выделенных штаммов) и наличие 2-х генотипов Coelastrella aeroterrestrica в одной почвенной пробе. Данный вид наземных водорослей ранее выявлен в Европе, а также в России. Является новым видом для РДВ. Coelastrella oocystiformis (J.W.G.Lund) E.Hegewald \& N.Hanagata - 1 штамм из одной пробы (точка 3; MW013809; табл.). Вид широко распространен: Англия, Чехия, Китай, Корея, Россия. Является новым видом для РДВ. Bracteacoccus sp. - второй потенциально новый вид, характеризующийся низкой иден- 
тичностью ITS-региона ярДНК по результатам BLAST (85,4\%). Один штамм Parietochloris pseudoalveolaris (T.R.Deason \& Bold) Shin Watanabe \& G.L.Floyd in Deason, Silva, Watanabe \& Floyd (MW013814; табл.). Вид широко распространен и выявлен в почвах Украины, Швеции, Чили, США, Тайваня и России. Является новым видом для Сахалинской области и о. Итуруп. Coccomyха subellipsoidea E.Acton - один штамм из одной пробы (точка 3; MV013811; табл.). Вид широко распространен и отмечен в Европе, Африке, Северной Америке и даже в Антарктике. Однако в России он ранее не отмечался. Stichococcus sp. - третий потенциально новый вид, с низкой идентичностью по ITS-региону ярДНК (95,9\%).

Таким образом, использование молекулярных данных (анализ нуклеотидных последовательностей ITS-региона ярДНК) позволило достоверно определить видовую принадлежность 7 штаммов и выявить 3 потенциально новых вида, требующих дополнительного исследования. Использование сканирующей электронной микроскопии позволило определить 3 вида диатомей, а применение световой микроскопии - подтвердить правильность идентификации всех остальных штаммов водорослей. Ареалы выявленных видов зачастую очень обширны или еще не до конца установлены. Расстояние между некоторыми ранними находками и о. Итуруп составляет порядка десятка тысяч километров, что позволяет говорить о практически космополитном распространении некоторых видов водорослей (например, Cоссотуха subellipsoidea, Coelastrella aeroterrestrica). В то же время в одной пробе могут встретиться два генетически дивергентных штамма одного вида (Coelastrella aeroterrestrica). В результате сравнения предыдущего исследования вулканических почв острова Итуруп [4] с полученными данными было отмечено более низкое число выявленных видов (23 и 13 видов соответственно), отсутствие представителей цианобактерий и Xanthophyceae, наличие водорослей класса Eustigmatophyceae, отсутствие общих видов. При этом в обоих случаях доминировали представители отдела Chlorophyta (12 и 7 видов соответственно). Возможно, такие отличия обусловлены разными экологическими условиями изученных местообитаний: тип почвы, состав высшей растительности и т.д.

Известно, что от характера наземной растительности в значительной степени зависит состав и количество почвенных цианобактерий и водорослей, выступающих как составные части лесных экосистем. В частности, высшими растениями определяется световой режим в лесу. Недостаток света, связанный с густым растительным покровом или наличием мощной подстилки обусловливает снижение развития цианобактерий и водорослей в почвах $[12,13]$. Именно поэтому, вероятно, низкое видовое богатство водорослей в изученных пробах почвы под Бамбучником связано, в первую очередь, с сильной затененностью местообитания, так как этот вид высших растений образует очень густой травостой, а также с большим количеством листового и стеблевого опада на почве. Возможно, на видовой состав повлиял также и тип почвы (дерновоперегнойные охристые буроземы), однако уточнение этого вопроса требует дальнейших исследований.

Исследование выполнено за счет гранта Российского научного фоонда № 21-1400196, https: //rscf.ru/project/21-14-00196/ 


\section{Литература}

1. Баринова С. С. Пресноводные диатомовые водоросли Курильских островов. В кн.: Систематика и экология речных организмов. Владивосток: ДВО АН СССР. 1989. С. 138-141.

2. Медведева Л. А., Никулина Т. В. Каталог пресноводных водорослей юга Дальнего Востока России. Владивосток: Дальнаука. 2014. С. 271.

3. Штина Э. А., Андреева В. М., Кузякина Т. И. Заселение водорослями вулканических субстратов // Ботанический журнал. 1992. Т. 77. № 8. С. 33-42.

4. Ilchibaeva K. V., Kunsbaeva D. F., Allaguvatova R. Z., Fazlutdinova A. I., Polokhin O. V., Sibirina L. A., Gontcharov A. A., Singh P., Gaysina L. A. Preliminary data about algae and cyanobacteria of volcanic soils on Kuril Islands // Theor. Appl. Ecol. 2018. V. 4. P. 119-126.

5. Костенков Н. М., Ознобихин В. И. Почвенно-географическое районирование Курильских островов // Вестник СВНЦ ДВО РАН. 2011. № 1. С. 77-83.

6. Полохин О. В., Сибирина Л. А. Почвенный и растительный покров острова Итуруп (Курильские острова) // Современные проблемы науки и образования. 2014. № 5. C. 618 .

7. Голлербах М. М., Штина Э. А. Почвенные водоросли. Л.: Наука. 1969. С. 228.

8. База данных BLAST (Basic Local Alignment Search Tool), National Center for Biotechnology Information, U.S. National Library of Medicine // [Электронный ресурс]. https://blast.ncbi.nlm.nih.gov/Blast.cgi (дата обращения: 14.07.2021).

9. Abdullin Sh. R. Cyanobacterial-algal cenoses of the Shulgan-Tash cave, Southern Urals // Russ. J. Ecol. 2009. V. 40. № 4. P. 301-303.

10. Abdullin Sh. R. Effect of illumination on the distribution of phototrophic organisms in the entrance part of the Shulgan-Tash cave // Russ. J. Ecol. 2011. V. 42. № 3. P. 249-251.

11. Костиков И. Ю. Альгогруппировки некоторых почв Уссурийского заповедника (Приморский край, Россия) // Альгология. 1994. Т. 4. № 4. С. 40-44.

12. Алексахина Т. И., Штина Э. А. Почвенные водоросли лесных биогеоценозов. М.: Наука. 1984. С. 150.

13. Новичкова-Иванова Л. Н. Почвенные водоросли подзоны широколиственнохвойных лесов Амуро-Зейского междуречья. В кн.: Амурская тайга. Л.: Наука. 1969. С. 127-153. 
The study of the diversity of algae in soils under the vegetation of Sasa kurilensis on Iturup Island, Russia using molecular genetic approach
A. Yu. Nikulin ${ }^{1}$, V.
B. Bagmet ${ }^{1}$, V. Yu. Nikulin ${ }^{1}$, Sh. R. Abdullin ${ }^{1}$
${ }^{1}$ Federal Scientific Center of the East Asia Terrestrial Biodiversity of the Far Eastern Branch, Russian Academy of Sciences
159 100-Letia Vladivostoka Prospect, 690022, Vladivostok, Russia.

\section{*Email: artyrozz@mail.ru}

The first data on biodiversity of algae in soils under vegetation with Sasa kurilensis (Rupr.) Makino \& Shibata on Iturup Island (Russia) were obtained using classical algological and molecular methods. We found 13 algae species of 10 genera, 10 families, 7 orders, 4 classes and 3 phyla: Bacillariophyta - 3 species, Ochrophyta - 3 species, Chlorophyta - 7 species. All the species recorded are characterized by very extensive or not yet fully established ranges. The low species richness of the studied samples is apparently associated with the strong shading of the habitats under Sasa kurilensis.

Keywords: biodiversity, soil algae, polyphasic approach, Sasa kurilensis, Iturup Island. 